\title{
Consumption and Beef Price Changes on Demand in East Nusa Tenggara, Indonesia
}

\author{
Doppy Roy Nendissa ${ }^{1}$, Ratya Anindita ${ }^{2}$, Nikmatul Khoiriyah ${ }^{3}$, Ana Arifatus Sa'diyah ${ }^{4}$ \\ ${ }^{1}$ Department of Agribusiness, Faculty of Agriculture, University of Nusa Cendana Kupang, Indonesia \\ ${ }^{2}$ Department of Socio-economics, Faculty of Agriculture, University of Brawijaya, Malang, Indonesia \\ ${ }^{3}$ Deparment of Agribusiness, Faculty of Agriculture, University of Islam Malang, Indonesia \\ ${ }^{4}$ Deparment of Agribusiness, Faculty of Agriculture, University of Tribhuwana Tunggadewi, Malang, \\ Indonesia
}

\begin{abstract}
Households consume animal protein after carbohydrate food is fulfilled, moreover animal protein prices are increasing. This study aims to analyze the effect of rising beef prices on demand. The demand system approach uses the Quadratic Almost Ideal Demand System (QUAIDS) model. Estimation of parameters using Iterated non-linear Seemingly Unrelated Regression. The research data use the 2016 National SocioEconomic Survey (Susenas, 2016), amounting to 10,751 households. The results of the study concluded that beef is the third most elastic animal food after fresh fish and chicken meat. Fresh fish in the most elastic among all animal foods with a demand elasticity of $3.31 \%$, followed by chicken, beef, milk powder, and eggs with demand elasticities of $1.55 \%, 1.62 \%, 1.29 \%$, and $0.80 \%$, respectively. Beef is a luxury item with an income elasticity of $1.59 \%$, as well as fresh fish, chicken meat, and milk powder. While eggs are normal goods. Although fresh fish is more elastic than beef, beef marginal expenditure share (MES) is higher than fresh fish MES, so that in the long run, the increase in household income tends to increase beef consumption more than fresh fish.
\end{abstract}

\section{Keywords}

Beef prices, animal food demand, elasticity, luxurious good, marginal expenditure share.

Nendissa, D. R., Anindita, R., Khoiriyah, N. and Sa'diyah A. A. (2021) "Consumption and Beef Price Changes on Demand in East Nusa Tenggara, Indonesia", A GRIS on-line Papers in Economics and Informatics, Vol. 13, No. 2, pp. 97-107. ISSN 1804-1930. DOI 10.7160/aol.2021.130208.

\section{Introduction}

To eliminate hunger, achieve food security and proper nutrition, and improve sustainable agriculture is the second objective of Sustainable Development Goals (SDGs). Two indicators in the SDGs objectives that are directly related to nutritional status are the prevalence of energy shortages (prevalence of undernourishment) and the prevalence of populations with moderate or severe food insecurity. The adequacy level of energy and protein consumption can be used as an indicator to look at the nutritional conditions of the community and also the success of the government in integrated food, agriculture, health and socio-economic development (Ariani, 2010). To realize the second goal of the SDGs are food sufficiency, including protein adequacy, is very important (Robert et al., 2005).
Monthly average expenditure per capita (quantity and value) of food items, March 2016 in East Nusa Tenggara (NTT) for fresh fish and shrimp is $1.18 \mathrm{~kg}$ (Rp. 22,978), preserved fish and shrimp is 0.57 gram (Rp. 2,360), beef is $0.03 \mathrm{~kg}$ (Rp. 2,276), chicken meat is $0.19 \mathrm{~kg}$ (Rp. 8,814), chicken egg is 2.53 unit (Rp. 5,335), duck egg is 0.01 unit (Rp. 25), sweeted condensed milk are $0.05 / 397$ grams (Rp. 522), infant formula is $0.03 \mathrm{~kg}$ (Rp. 2,524). Household consumption of animal protein is still below national monthly average expenditure per capita. Monthly average expenditure per capita in Indonesia for fresh fish is $2.99 \mathrm{~kg}$ (Rp. 28,969), preserved fish and shrimp is 1.29 gram (Rp. 4,651), beef is $0.03 \mathrm{~kg}$ (Rp. 3,791), chicken meat is 0.48 (Rp. 14,239), chicken egg is 8.51 unit (Rp. 11,778), duck egg is 0.36 unit (Rp. 347), sweeted condensed milk are $0.34 / 397$ grams (Rp. 3,156), infant formula is $0.05 \mathrm{~kg}$ (Rp. 4,909). 
The consumption of animal foods (beef, pork, chicken, and other meat) is much lower than in the United States (Katare et al., 2020).

Indonesian beef consumption is still very low, only $2.56 \mathrm{~kg}$ per capita per year compared to other ASEAN countries such as Vietnam $9.9 \mathrm{~kg} /$ capita/ year, Malaysia and Singapore $15 \mathrm{~kg} /$ capita/ year, while Germany is 40-45 kg/capita/year and the highest in Brazil reaching $55 \mathrm{~kg}$ per capita per year (Central Bureau of Statistics, 2018). Indonesian meat consumption is increasing, but an increase does not follow the increase in domestic production, so it must be imported. Indonesia imports the most massive beef from Brazil and Australia because prices are more competitive (Nendissa et al., 2019), empirically, we find that NTT is one of the biggest beef producing regions in Indonesia. However, during this time, NTT beef production was sent out of the province for household consumption in NTT. So this condition causes the level of meat consumption per capita in NTT below.

Research on food demand systems has been carried out in several country i.e. in Switzerland (Abdulai, 2002), in Semarang-Indonesia (Abdullah et al., 1994), in Ethiopia (Alem, 2011), in Pakistan (Naz et al., 2018). Research on food demand systemspecial for beef and also food consumption preferences, and food consumption patterns has been carried out in several country i.e. in Indonesia (Hutasuhut et al., 2002), in Nigeria (Ugwumba and Effiong, 2013), in Japan (Mahbubi et al., 2019), in Kenya (Korir et al., 2018), in (Kharisma et al., 2020), in Ethiopia (Tefera et al., 2018; Alem, 2011) (Abegaz et al., 2018), in Germany (Kaliji et al., 2019), and in India (Law et al., 2020). Research on the change in price elasticities in the U.S. beef cattle also has been carriet out (Jeong, 2019) using two budgeting model, also about beef consumption carriet out by Katare et al., (2020), (Andreyeva et al., 2010), (Schroeder et al., 2000). In Eropa has also been done by Roosen et al., (2003), Braschler (1983). Research on beef in East Nusa Tenggara, among others, has been carried out by (Nendissa et al., 2018). This research is about marketing namely, structure, conduct, and performance (SCP). However, research on consumption and changes in beef prices on demand is still rarely found. Therefore this study aims to analyze the effect of price and income changes on-demand at the household level. The demand system approach uses the Quadratic Almost Ideal Demand System (QUAIDS) model with parameter estimation using Iterated Non-linear Seemingly Unrelated
Regression (Mittal, 2010). The parameter estimation results are used to calculate the price elasticity itself so that information will be obtained whether the beef is elastic, inelastic, or unitary elastic (Dávila, 2010; Negi, 2018). Cross price elasticities will also be calculated so that it is known whether beef with other animal foods is substitution or complementary. Estimation results of the parameters will also be calculated income elasticity so that it will be known whether beef is a luxury item, normal or inferior (Coelho and Aguiar, 2007, Alderiny and Ahmed, 2019). At the end of the analysis, a marginal expenditure share (MES) will be calculated in five animal food groups, to see the impact of changes in income on demand in the long run (Kumar and Kaur, 2017; Kaur and Kaur, 2020). The results of the study can be used to develop price or income policy scenarios to support the fulfillment of protein consumption, especially in East Nusa Tenggara (ENT).

\section{Materials nad methods}

\section{Model Specification: Quadratic Almost Ideal Demand System (QUAIDS)}

The most commonly used method in demand analysis in the last two decades is AIDS model developed by (Deaton and Muellbauer, 1980). The AIDS model has a number of some demand properties such as testing for symmetry and homogeneity through linier restriction among the commodities (Banks et al., 1997) generalized the AIDS model by demonstrating that the appropriate form for some consumer preferences is of a quadratic nature contrary to the linier form in the basic AIDS. In addrition, the QUAIDS model maintains the theory consistency and the demand properties of the AIDS model.

The approach of estimating QUAIDS, using the household consumption and expenditure survey. On the basis of selected five commodity animal food groups, which are indexed by $i$, we estimate a system of demand equations, consisting of total of animal protein consumption expenditure $m$, expenditure shares $w_{i}$ and commodity prices $p_{i}$. The estimation of our system of demand equations following (Poi, 2012a), using non-linear, Seemingly Unrelated Regression (SUR). Based on the non-parametric analysis of consumer spending patterns, it appears that the Engel curve requires a higher order of logarithm expenditure. The QUAIDS model has almost the same features as AIDS and can capture the curvature of Engel. Therefore, QUAIDS has been chosen as the demand model for estimated empirical strategies. As with the general demand 
system model, the AIDS model is determined by the following food budget shares $\left(w_{i}\right)$ :

$w_{i}=\frac{p_{i} q_{i}}{m}$,

where $p_{i}$ is price of $i, q_{i}$ is quantity of $i$, and $m$ is total expenditure, so demand system:

$w_{i}=\alpha_{i}+\sum_{j=1}^{k} \gamma_{i j} \ln p_{j}+\beta_{i} \ln \left[\frac{m}{a(\mathbf{p})}\right]$,

where $p_{j}$ is price of $j$ and $a(\mathrm{p})$ is index price of total expenditure:

$$
\begin{aligned}
\ln a(\mathbf{p}) & =\alpha_{0}+\sum_{i=1}^{k} \alpha_{i} \ln p_{i}+ \\
& +\frac{1}{2} \sum_{i=1}^{k} \sum_{j=1}^{k} \gamma_{i j} \ln p_{i} \ln p_{j}
\end{aligned}
$$

As well as the AIDS model, the QUAIDS model also needs restrictions to be consistent with utility maximization, i.e.:

Adding up:

$\sum_{i=1}^{k} \alpha_{1}=1, \sum_{i=1}^{k} \beta_{i}=0, \sum_{i=1}^{k} \gamma_{i j}=0$

Homogeneity: $\sum_{j=1}^{k} \gamma_{i j}=0$, and

Slutsky's symmetry: $\gamma_{i j}=\gamma_{j i}$

Restriction on demand theory (4), (5) and (6) are imposed during estimation and ensure that notation (3) defines $a$ (p) as a linearly homogeneous function of the individual prices. Further, where notation (4), (5) and (6) hold, notation (2) provides a system of demand function which add up to total expenditure $\left(\sum w_{i}=1\right)$, is homogeny as long as prices and income are zero according to the Slutsky Symmetry theory (Deaton, 1980). So, that the AIDS model can interpreted: as price $\left(p_{j}\right)$ and real expenditure $\left(\frac{m}{\mathrm{a}(\mathbf{p})}\right)$ is not change, so share of expenditure $\left(w_{i}\right)$ is constant $\left(\alpha_{i}\right)$.

A development of the AIDS model, the QUAIDS model was proposed by Banks et. al (1997), namely by adding an element of quadratic logarithm of expenditure. This follows the nature of flexibility the Engel curve share of household expenditure is not linear, and some commodities are staple goods and some commodities are luxury goods (Banks et al., 1997b). The QUAIDS model in budget share is:

$$
\begin{aligned}
w_{i} & =\alpha_{i}+\sum_{j=1}^{k} \gamma_{i j} \ln p_{j}+\beta_{i} \ln \left[\frac{m}{a(\mathbf{p})}\right]+ \\
& +\frac{\lambda_{i}}{b(\mathbf{p})}\left\{\ln \left[\frac{m}{a(\mathbf{p})}\right]\right\}^{2}
\end{aligned}
$$

The term equals equation (2) and $b(p)$ is the CobbDouglas aggregate price, written as follows:

$$
b(\mathbf{p})=\prod_{j=1}^{k} p_{i}^{\beta_{i}}
$$

In the consumer demand theory, adding-up conditions are also needed:

$$
\sum_{j=1}^{k} \lambda_{j}=0
$$

When entering the household socio-demographic variable, based on the expenditure function (cost) as follows:

$$
e(\mathbf{p}, \mathbf{z}, u)=m_{0}(\mathbf{p}, \mathbf{z}, u) \times e^{R}(\mathbf{p}, u)
$$

Where $\mathrm{z}$ is a vector of household characteristics, $e^{R}(\mathrm{p}, \mathrm{u})$ is expenditure function, and $m_{0}(\mathrm{p}, \mathrm{z}, \mathrm{u})$ scale of the expenditure function that can be obtained from:

$m_{0}(\mathbf{p}, \mathbf{z}, u)=\bar{m}_{0}(\mathbf{z}) \times \phi(\mathbf{p}, \mathbf{z}, u)$

where $m_{0}$ measure the increase in household expenditure as a function of $z$, and $\phi$ is a change in the price of goods consumed. So, $m_{0}(z)$ is:

$\bar{m}_{0}(\mathbf{z})=1+\rho^{\prime} \mathbf{z}$

where $\rho$ is a vector estimate parameters, $\phi(\mathrm{p}, \mathrm{z}, \mathrm{u})$ is a parameter of:

$\ln \phi(\mathbf{p}, \mathbf{z}, u)=\frac{\prod_{j=1}^{k} p_{j}^{\beta_{i}}\left(\Pi_{j=1}^{k} p_{j}^{\eta_{j}^{\prime}}-1\right)}{\frac{1}{u}-\sum_{j=1}^{k} \lambda_{j} \ln p_{j}}$

Where $\eta_{j}$ describes the column to $j$ of the matrix parameter $\eta$. To adhere to consumer demand theory, a further adding-up condition is required, given as

$\sum_{i=1}^{k} \eta_{r j}=0$

for $r=1 \ldots, s$. The estimation of the QUAIDS animal food model in East Nusa Tenggara, Indonesia can be written into the formula:

$$
\begin{gathered}
w_{i}=\alpha_{i}+\sum_{j=1}^{\mathrm{k}} \lambda_{j} \ln p_{j}+\left[\frac{m}{\bar{m}_{0}(z) \alpha(p)}\right] \\
+\frac{\lambda_{i}}{b(\mathrm{p}) c(\mathrm{p}, z)}\left\{\ln \left[\frac{m}{\bar{m}_{0}(z) a(\mathrm{p})}\right]\right\}^{2}+\varepsilon
\end{gathered}
$$

where

$c(\mathbf{p}, \mathbf{z})=\prod_{j=1}^{k} p_{j}^{\eta_{j}^{\prime} z}$

The parameters generated from the QUAIDS model are used to calculate the own-price elasticity, cross price elasticity of both Hicksian and Marshallian, also expenditure elasticity. Marshallian (uncompensated) price elasticity is:

$$
\begin{aligned}
\epsilon_{i j}^{u} & =-\delta_{i j}+\frac{1}{w_{i}}\left(\gamma_{i j}-\left[\beta_{i}+\eta_{j}^{\prime} z+\frac{2 \lambda_{i}}{b(\mathbf{p}) c(\mathbf{p}, \mathbf{z})} \ln \left\{\frac{m}{a(\mathbf{p}) \bar{m}_{0}(\mathbf{z})}\right\}\right]\right. \\
& \left.\times\left(\alpha_{j}+\sum_{l} \gamma_{j l} \ln p_{l}\right)-\frac{\left(\beta_{i}+\eta_{j}^{\prime} z\right) \lambda_{i}}{b(\mathbf{p}) c(\mathbf{p}, \mathbf{z})}\left[\ln \left\{\frac{m}{a(\mathbf{p}) \bar{m}_{0}(\mathbf{z})}\right\}\right]^{2}\right)
\end{aligned}
$$


Expenditure (income) elasticity) is:

$\mu_{i}=1+\frac{1}{w_{i}}\left[\beta_{i}+\eta_{j}^{\prime} z+\frac{2 \lambda_{i}}{b(\mathbf{p}) c(\mathbf{p}, \mathbf{z})} \ln \left\{\frac{m}{a(\mathbf{p}) \bar{m}_{0}(\mathbf{z})}\right\}\right]$

Hicksian (compensated) elasticity is:

$$
\epsilon_{i j}^{c}=\epsilon_{i j}^{u}+w_{j} \mu_{i}
$$

Equation (1) to (6) adopted from Deaton and Muellbauer (1980), and equation (7) to (18) adopted from (Poi, 2012) with reference to Banks et al. (1997). The parameters are estimated by iterated feasible generalized non-linier least which are equivalent to the multivariate normal maximum likelihood estimator for this class of problem via Stata's 14.3 with 'NLSUR' command as suggested by Poi (2012).

\section{Maginal Expenditure Share}

Marginal Expenditure Share (MES) is the percentage change in demand for goods due to changes in income in the long run (Ackah and Appleton, 2007). MES is calculated from both own and cross-price Marshallian elasticities, both own and cross-price Hicksian elasticities, and expenditure elasticities. MES is calculated using the following formula:

$m_{i}=\eta_{i} \cdot w_{i}$

where:

$\epsilon_{i i}^{u}$ : Marshallian own-price elasticity

$\epsilon_{i j}^{u}$ : Marshallian cross-price elasticity

$\epsilon_{i i}^{c}$ : Hicksian own-price elasticity

$\epsilon_{i j}^{c}$ : Hicksian cross-price elasticity

$\eta_{i}$ : Expenditure elasticity

$m_{i}$ : Marginal expenditure share

\section{Data}

The data used in this research is secondary data, conducted by the Central Bureau of Statistics is in the form of household surveys, called the Susenas (National Socioeconomic Survey) data, March 2016. The data analyzed were socio-demographic data (household region status, total household member (HHsize), household consumption and expenditure, and total expenditure. This study's variables include the variable price of five animal food groups, namely egg price, chicken meat price, beef price, fresh fish price, and powdered milk price. The price variable is approximated by the expenditure of each animal food divided by the amount consumed. Besides price, there is also a consumption variable, namely consumption of the five animal food groups, namely consumption of eggs, chicken meat consumption, consumption of beef, consumption of fresh fish, and consumption of powdered milk.The animal foods observed in this study were eggs (chicken eggs, local chicken eggs, and duck eggs), chicken meat (local chicken meat and chicken meat), beef, fresh fish (fresh fish and shrimp including fish, shrimp, squid, and shellfish) as well as milk powder (milk powder and infant milk). The sample of this research is 10,751 households.

\section{Results and discussion}

\section{Factors affecting animal food demand}

The results of the QUAIDS analysis obtain parameter. The parameters obtained from the data analysis results are the constant parameter (alpha), the price parameter for the five animal food groups (beta), the income parameter for the five animal food groups (gamma), the income square parameter (lambda), the region status parameter (etha), and the HHsize parameter (rho). Parameter of prices, expenditure (income), the quadrat of income and demographic factors ie, HHsize, and region status (urban or rural) are almost all significant at alpha $1 \%$ to $5 \%$ (Table 1). All alpha (constant) parameters are significant, except the eggs group parameters are not significant. The price of beef, the price of eggs, and the price of milk powder are very significant (alpha 1\%). In comparison, the price of chicken meat and fresh fish is not significant. Animal food prices include the prices of five animal food groups, namely eggs prices, chicken meat prices, beef prices, fresh fish prices, and milk powder prices. Like AIDS, the QUAIDS model also fulfills three restrictions, namely adding-up, homogeneity, and symmetry.

All quadrat expenditures have a very significant effect on animal food demand except fresh fish. The coefficient quadrat income for eggs and fresh fish are positive, while chicken meat, beef, and milk powder are negative. This means that if household income doubles, the demand for eggs and fresh fish increases, while the demand for chicken meat, beef, and milk powder decrease. The negative coefficient sign indicates that goods tend to be fancy. In contrast, positive signs indicate that normal goods tend to be luxurious. So, eggs group and fresh fish are categorized as normal items, whereas chicken meat, beef, and milk powder tend to be luxury goods. Referring to the positive beef quadrat income parameter results, the policy to increase household income is considered very appropriate to increase beef consumption. 


\begin{tabular}{|c|c|c|c|c|c|c|}
\hline Parameter & Coef. & Std. Err. & $\mathbf{z}$ & $\mathbf{P}>|\mathbf{z}|$ & [95\% Conf. & Interval] \\
\hline \multicolumn{7}{|l|}{ Alpha (constant) } \\
\hline alpha_1 & -0.070 & 0.085 & -0.820 & 0.411 & -0.236 & 0.097 \\
\hline alpha_2 & 0.631 & 0.067 & 9.380 & $0.000^{* *}$ & 0.499 & 0.763 \\
\hline alpha_3 & 0.195 & 0.037 & 5.280 & $0.000^{* *}$ & 0.122 & 0.267 \\
\hline alpha_4 & 0.126 & 0.023 & 5.580 & $0.000^{* *}$ & 0.082 & 0.170 \\
\hline alpha_5 & 0.118 & 0.040 & 2.940 & $0.003 * *$ & 0.039 & 0.197 \\
\hline \multicolumn{7}{|l|}{ Beta (price) } \\
\hline beta_1 & 0.248 & 0.064 & 3.860 & $0.000^{* *}$ & 0.122 & 0.373 \\
\hline beta_2 & -0.055 & 0.046 & -1.180 & 0.238 & -0.146 & 0.036 \\
\hline beta_3 & -0.030 & 0.013 & -2.350 & $0.019 *$ & -0.055 & -0.005 \\
\hline beta_4 & -0.005 & 0.006 & -0.800 & 0.423 & -0.018 & 0.007 \\
\hline beta_5 & -0.158 & 0.015 & -10.430 & $0.000 * *$ & -0.188 & -0.128 \\
\hline \multicolumn{7}{|c|}{ Gamma (expenditure) } \\
\hline gamma_1_1 & 0.226 & 0.045 & 5.040 & $0.000^{* *}$ & 0.138 & 0.313 \\
\hline gamma_2_1 & -0.184 & 0.037 & -5.020 & $0.000^{* *}$ & -0.256 & -0.112 \\
\hline gamma_3_1 & -0.010 & 0.012 & -0.840 & 0.401 & -0.034 & 0.014 \\
\hline gamma_4_1 & 0.024 & 0.007 & 3.380 & $0.001 * *$ & 0.010 & 0.038 \\
\hline gamma_5_1 & -0.055 & 0.012 & -4.730 & $0.000 * *$ & -0.078 & -0.032 \\
\hline gamma_2_2 & 0.127 & 0.034 & 3.740 & $0.000 * *$ & 0.060 & 0.193 \\
\hline gamma_3_2 & 0.005 & 0.011 & 0.420 & 0.672 & -0.018 & 0.027 \\
\hline gamma_4_2 & 0.007 & 0.007 & 1.060 & 0.289 & -0.006 & 0.020 \\
\hline gamma_5_2 & 0.046 & 0.011 & 4.020 & $0.000^{* *}$ & 0.023 & 0.068 \\
\hline gamma_3_3 & -0.027 & 0.013 & -2.010 & $0.044^{*}$ & -0.054 & -0.001 \\
\hline gamma_4_3 & -0.009 & 0.006 & -1.610 & 0.107 & -0.020 & 0.002 \\
\hline gamma_5_3 & 0.042 & 0.008 & 4.960 & $0.000^{* *}$ & 0.025 & 0.058 \\
\hline gamma_4_4 & -0.015 & 0.005 & -2.950 & $0.003 * *$ & -0.025 & -0.005 \\
\hline gamma_5_4 & -0.007 & 0.006 & -1.200 & 0.230 & -0.017 & 0.004 \\
\hline gamma_5_5 & -0.026 & 0.013 & -1.970 & $0.049^{*}$ & -0.051 & 0.000 \\
\hline \multicolumn{7}{|c|}{ Lambda (quadrat of expenditure) } \\
\hline lambda_1 & 0.013 & 0.001 & 17.620 & $0.000^{* *}$ & 0.012 & 0.014 \\
\hline lambda_2 & -0.003 & 0.001 & -3.100 & $0.002 * *$ & -0.006 & -0.001 \\
\hline lambda_3 & -0.002 & 0.000 & -3.350 & $0.001 * *$ & -0.002 & -0.001 \\
\hline lambda_4 & 0.000 & 0.000 & -0.950 & 0.344 & -0.001 & 0.000 \\
\hline lambda_5 & -0.008 & 0.001 & -11.250 & $0.000^{* *}$ & -0.009 & -0.006 \\
\hline \multicolumn{7}{|c|}{ Etha (demography) } \\
\hline eta_urban_1 & -0.240 & 0.036 & -6.590 & $0.000^{* *}$ & -0.312 & -0.169 \\
\hline eta_urban_2 & 0.118 & 0.022 & 5.270 & $0.000^{* *}$ & 0.074 & 0.161 \\
\hline eta_urban_3 & 0.031 & 0.006 & 5.270 & $0.000 * *$ & 0.020 & 0.043 \\
\hline eta_urban_4 & 0.005 & 0.002 & 1.930 & $0.054^{*}$ & 0.000 & 0.009 \\
\hline eta_urban_5 & 0.087 & 0.010 & 8.710 & $0.000^{* *}$ & 0.067 & 0.107 \\
\hline eta_hhm_tot_1 & -0.002 & 0.001 & -3.300 & $0.001 * *$ & -0.003 & -0.001 \\
\hline eta_hhm_tot_2 & 0.002 & 0.000 & 4.530 & $0.000 * *$ & 0.001 & 0.003 \\
\hline eta_hhm_tot_3 & 0.000 & 0.000 & 2.030 & $0.042 *$ & 0.000 & 0.001 \\
\hline eta_hhm_tot_4 & 0.000 & 0.000 & 0.100 & 0.924 & 0.000 & 0.000 \\
\hline eta_hhm_tot_5 & 0.000 & 0.000 & -0.470 & 0.638 & -0.001 & 0.001 \\
\hline \multicolumn{7}{|l|}{ Rho } \\
\hline rho_urban & -0.499 & 0.000 & 1015.500 & $0.000^{* *}$ & -0.500 & -0.498 \\
\hline rho_hhm_tot & 0.000 & 0.000 & 1.950 & $0.052 *$ & 0.000 & 0.000 \\
\hline
\end{tabular}

Note: ** and * indicate significant at the $1 \%$ and $5 \%$ significance level, respectively

$1=$ eggs, $2=$ chicken meat, $3=$ =eef, $4=$ fresh fish, $5=$ milk powder, $\mathrm{hhm}=$ household member (HHsize)

Source: March 2016 Susenas, research findings

Table 1: QUAIDS Parameter estimates of animal food demand. 
Etha is a demographic variable parameter that is the settlement type or status of household residence (region) and the HHsize in each animal food. Almost all animal food prices, both in urban and rural prices, are significant to demand. In the HHsize variable, the significant HHsize is in the commodity eggs, chicken meat, and beef, while in fresh fish and powdered milk is not significant. This means that an increase in $\mathrm{HH}$ size decreases egg demand (negative coefficient sign). In contrast, an increase in HHsize increases demands chicken meat or beef (positive coefficient sign).

\section{Marshallian (uncompensated) own and cross-} price elasticity

The results of the QUAIDS model analysis produce parameters. From these parameters, it is used to calculate price and income elasticities as in equations (16), (17), and (18). Price elasticity includes own and cross-price elasticities, while price elasticity also includes Marshallian (uncompensated) and Hicksian (compensated) price elasticities. Table 2 shows the elasticity own-prices and the elasticity of Marshallian crossprices. All Marshallian own-price elasticities are negative. This is consistent with the economic theory that rising animal food prices reduce demand. Alternatively, in other words, rising prices for eggs, chicken meat, beef, fresh fish, and milk powder reduce the consumption of animal foods. Households reduce animal food consumption if there is an increase in prices.

The fresh fish group was the most elastic among all animal foods with a demand elasticity of $3.31 \%$, followed by chicken, beef, milk powder, and eggs with demand elasticities of $1.55 \%, 1.62 \%$, $1.29 \%$, and $0.80 \%$, respectively. An increase in the price of fresh fish by $1 \%$ decreases the demand for fresh fish by $3.31 \%$. East Nusa Tenggara is the second-largest beef producer after East Java. This is consistent with the results of the analysis that the elasticity of beef demand is below the elasticity of fresh fish. This means that the effect of rising beef prices is smaller than that of fresh fish because the region is a beef producer so that consumption of beef is far more accessible to households compared to provinces as consumers only.

Table 2 also shows the elasticity of Marshallian cross prices. The cross-price elasticity shows the relationship between animal food and others animal food. If the positive cross-price elasticity indicates a substitution relationship if the negative indicates a complementary relationship. The analysis shows that almost all Marshallian cross-price elasticities are positive, meaning that between animal foods is substitution. An increase in animal food prices increases the demand for other animal foods - fresh fish substitutes all other animal foods except milk powder, which is complementary. An increase in the price of fresh fish $1 \%$ increases beef demand by $0.24 \%$, chicken meat by $0.09 \%$, and eggs by $0.05 \%$. Whereas with milk powder, it reduced demand by $0.02 \%$. This study's results are different from studies in America that the elasticity of beef is less than one or so-called inelastic goods (Katare et al., 2020). Indonesia is a developing country, so that price changes have a more significant response than developed countries such as America. The consumption of beef is also higher in America than in Indonesia.

Beef is a substitution with all other animal foods. An increase in beef price by $1 \%$ decreases demand for beef and increases the demand for fresh fish by $0.52 \%$, then powdered milk, eggs, and chicken meat, respectively $0.03 \%, 0.02 \%$, and $0.003 \%$.

\begin{tabular}{|c|c|c|c|c|c|}
\hline Animal food group & Eggs & Chicken meat & Beef & Fresh fish & Milk powder \\
\hline \multirow{2}{*}{ Eggs } & -0.800 & 0.203 & 0.016 & 0.052 & 0.060 \\
\hline & $(0.004)$ & $(0.004)$ & $(0.002)$ & $(0.002)$ & $(0.003)$ \\
\hline \multirow{2}{*}{ Chicken meat } & -0.168 & -1.623 & 0.003 & 0.093 & 0.027 \\
\hline & $(0.009)$ & $(0.010)$ & $(0.004)$ & $(0.004)$ & $(0.006)$ \\
\hline \multirow{2}{*}{ Beef } & -0.270 & -0.001 & -1.548 & 0.244 & 0.099 \\
\hline & $(0.018)$ & $(0.020)$ & $(0.021)$ & $(0.013)$ & $(0.017)$ \\
\hline \multirow{2}{*}{ Fresh fish } & -0.348 & 0.986 & 0.515 & -3.314 & 0.007 \\
\hline & $(0.037)$ & $(0.039)$ & $(0.025)$ & $(0.033)$ & $(0.033)$ \\
\hline \multirow{2}{*}{ Milk powder } & -0.330 & 0.020 & 0.033 & -0.019 & -1.292 \\
\hline & $(0.009)$ & $(0.010)$ & $(0.006)$ & $(0.006)$ & $(0.011)$ \\
\hline
\end{tabular}

Source: March 2016 Susenas, standart errors of means in parentheses

Table 2: Marshallian (uncompensated) own and cross-price elasticity. 
The power of substitution is small, so it can be said that animal food in East Nusa Tenggara is a close substitute. This also happens in chicken meat and milk powder, where the substitution power with other animal foods is also very low.

\section{Hicksian (compensated) own and cross-price elasticities}

The Hicksian (compensated) price elasticity is price elasticity when there is only the effect of price changes. Table 3 presents the own and cross-elasticity of Hicksian. In East Nusa Tenggara, all own-price elasticities are negative. This is consistent with the economic theory, which states that there is a negative relationship between the price and the quantity of goods demanded. Alternatively, in other words, rising prices reduce animal food consumption. Of the five animal food groups, the most elastic animal food groups are fresh fish, then beef, chicken meat, milk powder, and eggs, with Hicksian own-price elasticities of $3.26 \%, 1.47 \%, 1.25 \%, 1.05 \%$, and $0.54 \%$. Similar to Marshallian own-price elasticity, fresh fish are also the most elastic, but Hicksian own-price elasticity is smaller than Marshallian own-price elasticity. This is because the Hicksian price elasticity only contains a substitution effect. In contrast, the Marshallian price elasticity contains a substitution effect and income effect.

In contrast to the Marshallian cross-price elasticity, that all Hicksian cross-price elasticities are positive in animal food demand caused by the substitution effect alone. It means that the price increase has consequences for changes in the type of animal food consumed by households. Positive cross-price elasticity means an increase in animal food that one increases the demand for other animal foods, often called a substitution relationship. Fresh fish substituted with beef, chicken, eggs, and milk powder with cross elasticity of $0.28 \%, 0.14 \%$, $0.06 \%$, and $0.02 \%$. A $1 \%$ increase in the price of fresh fish increases beef demand by $0.28 \%$. Beef is substituted with fresh fish, powdered milk, chicken, and eggs with Hicksian cross-price elasticities of $0.62 \%, 0.11 \%, 0.09 \%$, and $0.06 \%$. The increase in prices accompanied by an increase in income increased demand for fresh fish by 0.05 points $(3,260-3,314)$.

The second most elastic animal food is beef. While the increase in beef prices accompanied by an increase in income increased beef demand by 0.075 points $(1,474-1,548)$. The implication of this research is an animal food price policy is needed, so that prices do not increase. Rising prices cause a decrease in all animal food consumption. This is in-line with the research (Khoiriyah et al., 2019)(Khoiriyah et al., 2020) that beef is very elastic in Indonesia, both in rural households and at various levels of poverty in Indonesia. Field information explains that the price of beef in the region in 2016 reached Rp. 100,000 to Rp. $110,000 / \mathrm{kg}$. But often cattle in the region are sold in the form of not beef but are sold to other provinces namely Jakarta and Kalimantan with an average price of Rp.27,000 to Rp. 32,000 per kg of live weight (Nendissa et al., 2018).

\section{Expenditure elasticity}

The demand for goods and services also depends on household income. Expenditure (income) elasticity shows the percentage change in demand as a result of the percentage change in income. The results of the analysis of income elasticity and Marginal Expenditure Share (MES) as in Table 4. Fresh fish is the most elastic among all animal foods, with an income elasticity of $2.16 \%$. A $1 \%$ increase in income increases the demand for fresh fish by $2.16 \%$. Chicken meat, milk powder, and beef are also elastic, which are respectively $1.67 \%, 1.59 \%$, and $1.48 \%$. Because the income elasticity of fresh fish, chicken meat, milk powder, and beef are greater than one, the four

\begin{tabular}{|c|c|c|c|c|c|}
\hline Animal food group & Eggs & Chicken meat & Beef & Fresh fish & Milk powder \\
\hline \multirow{2}{*}{ Eggs } & -0.542 & 0.308 & 0.040 & 0.064 & 0.131 \\
\hline & $(0.004)$ & $(0.004)$ & $(0.002)$ & $(0.002)$ & $(0.003)$ \\
\hline \multirow{2}{*}{ Chicken meat } & 0.749 & -1.249 & 0.087 & 0.136 & 0.278 \\
\hline & $(0.009)$ & $(0.010)$ & $(0.004)$ & $(0.004)$ & $(0.006)$ \\
\hline \multirow{2}{*}{ Beef } & 0.542 & 0.330 & -1.474 & 0.282 & 0.321 \\
\hline & $(0.019)$ & $(0.020)$ & $(0.021)$ & $(0.013)$ & $(0.017)$ \\
\hline \multirow{2}{*}{ Fresh fish } & 0.837 & 1.468 & 0.623 & -3.260 & 0.331 \\
\hline & $(0.036)$ & $(0.040)$ & $(0.025)$ & $(0.033)$ & $(0.033)$ \\
\hline \multirow{2}{*}{ Milk powder } & 0.543 & 0.376 & 0.112 & 0.021 & -1.053 \\
\hline & $(0.009)$ & $(0.010)$ & $(0.006)$ & $(0.006)$ & $(0.011)$ \\
\hline
\end{tabular}

Source: March 2016 Susenas, standart errors of means in parentheses

Table 3: Hickisan (compensated) own and cross-price elasticity. 
animal food groups are luxury goods. Whereas eggs are normal goods due to changes in egg demand as a result of an increase in egg prices, changing by less than one ie, $0.47 \%$. This is consistent with research in various countries that beef is also a luxury item (Acar et al. (2016), Aftab et al. (2017), Abegaz et al.(2018), Pangaribowo (2010).

\begin{tabular}{lcc}
\hline $\begin{array}{l}\text { Animal Food } \\
\text { Groups }\end{array}$ & $\begin{array}{c}\text { Expenditure } \\
\text { Elasticity }\end{array}$ & $\begin{array}{c}\text { Marginal } \\
\text { Expenditure Share }\end{array}$ \\
\hline Eggs & 0.470 & 0.067 \\
Chicken meat & 1.668 & 0.054 \\
Beef & 1.476 & 0.266 \\
Fresh fish & 2.155 & 0.140 \\
Milk powder & 1.589 & 0.217 \\
\hline
\end{tabular}

Source: Author's calculations from Susenas

Table 4: Expenditure elasticity and marginal expenditure share.

Table 4 also presents Marginal Expenditure Share (MES). MES describes the additional changes in the amount requested as a result of changes in income but in the long run (Anindita et al., 2020; Sa'diyah et al., 2019). MES is important to analyze because it can be used, among other things, to develop price or income policy scenarios to achieve a recommended dietary allowance (RDA) according to the national RDA that is 57 grams/capita/day. MES beef is the biggest. This means that in the long run, households in NTT increase beef consumption if there is an increase in income. Likewise, milk powder, also experienced an increase in demand if there was an increase in income. The highest to lowest order of increasing demand (MES) is the consumption of beef, milk powder, fresh fish, eggs and chicken meat respectively by $0.266 \%, 0.217 \%, 0.14 \%$, $0.067 \%$, and $0.054 \%$. Although fresh fish is more elastic than beef. beef MES is bigger than fresh fish MES. This means an increase in income, in the long run encourages households to increase beef consumption more than eating fresh fish.

\section{Conclusion}

This paper presents on analyzing the impact of changes in prices, incomes, and demographic factors on animal food demand in East Nusa Tenggara. The demand system approach uses the Quadratic Almost Ideal Demand System (QUAIDS) model using parameters using Iterated non-linear Seemingly Unrelated Regression. The research data uses secondary data collected by the Central Bureau of Statistics for household consumption and expenditure data through the 2016 National Socio-Economic Survey
(Susenas). The sample of this study was 10.751 households. The results of the study concluded that the fresh fish group was the most elastic among all animal foods with a demand elasticity of $3.31 \%$, followed by chicken meat, beef, milk powder and eggs with demand elasticities of $1.55 \%, 1.62 \%$, $1.29 \%$, and $0.80 \%$, respectively. An increase in the price of fresh fish by $1 \%$ decreases the demand for fresh fish by $3.31 \%$. Demand for beef is elastic.

Fresh fish is the most elastic of all animal foods, with an income elasticity of $2.16 \%$. A $1 \%$ increase in income increases the demand for fresh fish by $2.16 \%$. Chicken meat, milk powder, and beef are also elastic, which are respectively $1.67 \%$, $1.59 \%$, and $1.48 \%$. Four groups of animal food are fresh fish, beef, chicken meat, and milk powder, including luxury goods, while eggs are normal goods. The highest to the lowest order of Marginal Expenditure Share (MES) is the consumption of beef, powdered milk, fresh fish, eggs, and chicken meat with MES, respectively, by $0.266 \%, 0.217 \%, 0.14 \%, 0.067 \%$, and $0.054 \%$. Although fresh fish is more elastic than beef, beef MES is higher than fresh fish MES. This means an increase in income, in the long run, encourages households to add more beef consumption than fresh fish.

East Nusa Tenggara is one of the biggest beef producing regions in Indonesia. Beef production is shipped out of the province rather than for household consumption in the region. This condition causes the level of per capita meat consumption in East Nusa Tenggara below. To increase beef consumption in East Nusa Tenggara, the government needs to provide income policies that can increase household purchasing power for beef. This is reinforced by the results of research beef income elasticity of 1,476 (quite elastic). The increase in household income by $1 \%$ increased beef consumption is higher than the increase in beef prices, which is increased by $1.48 \%$. While in the long run, a $1 \%$ increase in beef income increases beef consumption by $0.27 \%$. This increase, in the long run, is the biggest among all animal foods in East Nusa Tenggara.

\section{Acknowledgments}

Acknowledgment is submitted to the Central Bureau of Statistics for providing the best stewards in purchasing the micro data "consumption and household expenditure module". 
Corresponding authors

Nendissa, D. R.

Department of Agribusiness, Faculty of Agriculture, University of Nusa Cendana Kupang,

Adisucipto Penfui, Kupang, East Nusa Tenggara, P.C. 85111, Indonesia

Phone: +62380881586, E-mail: roynendissa@staf.undana.ac.id.

\section{References}

[1] Abdulai, A. (2002) "Household demand for food in Switzerland. A quadratic almost ideal demand system", Swiss Journal of Economics and Statistics (SJES), Swiss Society of Economics and Statistics (SSES), Vol. 138, No. 1, pp. 1-18. ISSN 2235-6282.

[2] Abdullah, N. M. R., Ghaffar, R. A. and Poerwono, D. (1994) “An almost ideal demand system analysis of fresh fish in Semarang, Indonesia ", Journal of International Food \& Agribusiness Marketing, Vol. 6, No.3, pp. 19-28. ISSN 0897-4438.

[3] Abegaz, G. A., Hassen, I. W. and Minten, B. (2018) "Consumption of animal-source foods in Ethiopia: Patterns, changes, and determinants", International Food Policy Research Institute, ESSP Working paper, $27 \mathrm{p}$.

[4] Acar, E. Ö., Günalp, B. and Cilasun, S. M. (2016) "An empirical analysis of household education expenditures in Turkey”, International Journal of Educational Development, Vol. 51, pp. 23-35. ISSN 0738-0593. DOI 10.1016/j.ijedudev.2016.03.007.

[5] Ackah, C. and Appleton, S. (2007) "Food price changes and consumer welfare in Ghana in the 1990s", CREDIT Research Paper. [Online]. Available: https:/www.researchgate.net/publication/5199919 Food_Price_Changes_and_Consumer_Welfare_in_Ghana_in_the_1990s [Accessed: 15 Jan., 2020].

[6] Aftab, S., Yaseen, M. R. and Anwar, S. (2017) "Impact of rising food prices on consumer welfare in the most populous countries of South Asia”, International Journal of Social Economics, Vol. 44, No. 8. ISSN 0306-8293. DOI 10.1108/IJSE-01-2016-0016.

[7] Alderiny, M. M. and Ahmed, S. B. (2019) "Analysis Of Saudi Demand For Imported Broiler Chickens", JAPS, Journal of Animal and Plant Sciences", Vol. 29, No. 3, pp. 833-841. ISSN 1018-7081.

[8] Alem, Y. (2011) "The impact of food price inflation on consumer welfare in urban Ethiopia: A quadratic almost ideal demand system approach", Economic Studies Department of Economics School of Business, Economics and Law University of Gothenburg, 54 p.

[9] Andreyeva, T., Long, M. W. and Brownell, K. D. (2010) "The impact of food prices on consumption: A systematic review of research on the price elasticity of demand for food", American Journal of Public Health, Vol. 100, No. 2, pp. 216-222. ISSN 1541-0048. DOI 10.2105/AJPH.2008.151415.

[10] Anindita, R., Sadiyah, A. A., Khoiriyah, N. and Nendyssa, D. R. (2020) "The demand for beef in Indonesian urban", In IOP Conference Series: Earth and Environmental Science, Vol. 411, No. 1, IOP Publishing.

[11] Ariani, M. (2010) "Analisis konsumsi pangan tingkat masyarakat mendukung pencapaian diversifikasi pangan", Gizi Indonesia, Vo. 33, No. 1. E-ISSN 2338-3119. DOI 10.36457/gizindo.v33i1.84.

[12] Banks, J., Blundell, R. and Lewbel, A. (1997) "Quadratic Engel curves and consumer demand", Review of Economics and Statistics, Vol. 79, No. 4, pp. 527-539. ISSN 0034-6535.

[13] Braschler, C. H. (1983) "The changing demand structure for pork and beef in the 1970s: Implications for the 1980s", Southern Journal of Agricultural Economics, Vol. 15, pp. 105-110. ISSN 0081-3052.

[14] Coelho, A. B. and Aguiar, D. (2007) "O modelo quadratic almost ideal demand system (quaids): Uma aplicação para o brasil”, In Gasto e Consumo Das Famílias Brasileiras Contemporâneas, pp. 485-514. ISBN 9788586170850.

[15] Dávila, O. G. (2010) "Food security and poverty in Mexico: The impact of higher global food prices”, Food Security, Vol. 2, No. 4, pp. 383-393. ISSN 1876-4517. 
[16] Deaton, A. and Muellbauer, J.(1980) "Economics and Consumer Behavior", Cambridge University Press, UK.

[17] Deaton, A. and Muellbauer, J. (1980) "An almost ideal demand system", The American Economic Review, Vol. 70, No. 3, pp. 312-326. ISSN 0002-8282.

[18] Hutasuhut, M., Chang, H.-S., Griffith, G., O’Donnell, C. and Doran, H. (2002) The Demand for Beef in Indonesia: Implications for Australian Agribusiness", Australasian Agribusiness Review, University of Melbourne, Vol. 10, pp. 1-10. ISSN 1442-6951. DOI 10.22004/ag.econ.206155.

[19] Jeong, S. (2019) "The Change in Price Elasticities in the US Beef Cattle Industry and the Impact of Futures Prices in Estimating the Price Elasticities", paper presented at the NCCC-134 Conference on Applied Commodity Price Analysis, Forecasting, and Market Risk Management, Minneapolis, Minnesota, April 15-16, 2019.

[20] Kaliji, S. A., Mojaverian, S. M., Amirnejad, H. and Canavari, M. (2019) "Factors Affecting Consumers' Dairy Products Preferences", AGRIS on-Line Papers in Economics and Informatics, Vol. 11, No. 2, pp. 3-11. ISSN 1804-1930 DOI 10.22004/ag.econ.294150.

[21] Katare, B., Wang, H. H., Lawing, J., Hao, N., Park, T. and Wetzstein, M. (2020) "Toward Optimal Meat Consumption", American Journal of Agricultural Economics, Vol. 102, No. 2, pp. 662-680. ISSN 0002-9092. DOI 10.1002/ajae.12016.

[22] Kaur, G. and Kaur, A. (2020) "Income and Expenditure Pattern of Marginalised Categories of Rural Punjab", Indian Journal of Economics and Development, Vol. 16, No. 1, pp. 137-141. ISSN 2277-5412.

[23] Kharisma, B., Alisjahbana, A. S., Remi, S. S. and Praditya, P. (2020) "Application of the Quadratic Almost Ideal Demand System (QUAIDS) Model in the Demand of the Household Animal Sourced Food in West Java", Agris on-Line Papers in Economics and Informatics, Vol. 12, No. 1, pp. 23-35. ISSN 1804-1930. DOI 10.7160/aol.2020.120103.

[24] Khoiriyah, N., Anindita, R., Hanani, N. and Muhaimin, A. W. (2019) "Animal Food Demand in Indonesian Rural: A Quadratic Almost Ideal Demand System Approach", WACANA, Jurnal Sosial Dan Humaniora, Vol. 22, No. 2, pp. 85-90. ISSN 2338-1884.

[25] Khoiriyah, N., Anindita, R., Hanani, N. and Muhaimin, A. W. (2020) "Animal Food Demand in Indonesia: A Quadratic Almost Ideal Demand System Approach", AGRIS on-line Papers in Economics and Informatics, Vol. 12, No. 2, pp. 85-97. ISSN 1804-1930. DOI 10.7160/aol.2020.120208.

[26] Korir, L., Rizov, M. and Ruto, E. (2018) "Analysis of household food demand and its implications on food security in Kenya: An application of QUAIDS model", 92 $2^{\text {nd }}$ Annual Conference, April 16-18, 2018, Warwick University, Coventry, UK.

[27] Kumar, D. and Kaur, A. (2017) "Credit Availed and Income-Expenditure Pattern of Marginal and Small Farmers in South Western Punjab", Journal of Agricultural Development and Policy, Vol. 27, No. 1 and 2,pp. 44-52. E-ISSN 2322-0457, ISSN 0974-9071.

[28] Law, C., Fraser, I. and Piracha, M. (2020) "Nutrition Transition and Changing Food Preferences in India", Journal of Agricultural Economics, Vol. 71, No. 1, pp. 118-143. E-ISSN 1477-9552. DOI 10.1111/1477-9552.12322.

[29] Mahbubi, A., Uchiyama, T. and Hatanaka, K. (2019) "Capturing consumer value and clustering customer preferences in the Indonesian halal beef market", Meat Science, Vol. 156, pp. 23-32. ISSN 0309-1740. DOI 10.1016/j.meatsci.2019.05.012.

[30] Mittal, S. (2010) "Application of the QUAIDS model to the food sector in India", Journal of Quantitative Economics, Vol. 8, No.1, pp. 42-54. ISSN 0971-1554.

[31] Naz, L., Ahmad, M. and Arif, G. M. (2018) "Estimating Food Demand System and Rural Household Welfare: A Case study from Pakistan", Business and Economic Review, Vol. 10, No.4, pp. 55-81. ISSN 2074-1693. DOI 10.22547/BER/10.4.3. 
[32] Negi, D. S. (2018) "The Welfare Impacts of High Food Prices: Resource Endowments and SpillOver Effects". [Online]. Available: https://www.semanticscholar.org/paper/The-Welfare-Impacts-ofHigh-Food-Prices\%3A-Resource-Negi/975a163362a2f9a99061ca79b6f5592d19aadefd. [Accessed: 20 Jan. 2020].

[33] Pangaribowo, E. H. (2010) "Food Demand Analysis of Indonesian Households: Do They Eat Better or SmoNe When They Get Richer", International Conference on Eurasian Economies, T.C. Beykent University, Istanbul - Turkey, 4-5 November 2010.

[34] Poi, B. P. (2012) "Easy demand-system estimation with quaids", The Stata Journal, Vol. 12, No. 3, pp. 433-446. ISSN 1536-867X. DOI 10.1177/1536867X1201200306.

[35] Robert, K. W., Parris, T. M. and Leiserowitz, A. A. (2005) "What is sustainable development? Goals, indicators, values, and practice", Environment: Science and Policy for Sustainable Development, Vol. 47, No. 3, pp. 8-21. ISSN 0013-9157. DOI 10.1080/00139157.2005.10524444.

[36] Roosen, J., Lusk, J. L. and Fox, J. A. (2003) "Consumer demand for and attitudes toward alternative beef labeling strategies in France, Germany, and the UK”, Agribusiness: An International Journal, Vol. 19, No. 1, pp. 77-90. ISSN 0742-4477.

[37] Roy, N. D., Ratya, A., Nuhfil, H. and Wahib, M. A. (2018) "Beef Market Integration In East Nusa Tenggara of Indonesia", Russian Journal of Agricultural and Socio-Economic Sciences, Vol. 80, No. 8, pp. 380-387. ISSN 2226-1184. DOI 10.18551/rjoas.2018-08.51.

[38] Sa'diyah, A. A., Anindita, R., Hanani, N. and Muhaimin, A. W. (2019) "The strategic food demand for non poor rural households in Indonesia", EurAsian Journal of BioSciences, Vol. 13, No. 2, pp. 2197-2202. ISSN 1307-9867.

[39] Schroeder, T. C., Marsh, T. L. and Mintert, J. (2000) "Beef demand determinants", Report Prepared for the Beef Board Joint Evaluation Advisory Committee.

[40] Tefera, N. U., Desta, M. D. and Rashid, S. (2018) "A Dynamic analysis of food demand patterns and habit effects: Panel evidence from rural households in Ethiopia", [Online]. Available: https://www.semanticscholar.org/paper/A-Dynamic-analysis-of-food-demand-patterns-and-fromUregia-Desta/81708513dcc74209b9ee983d55382052281e65bc [Accessed: 25 Jan. 2020].

[41] Ugwumba, C. O. A. and Effiong, J. A. L. (2013) "Analysis of Household Demand for Beef in Owerri Metropolis of Imo State, Nigeria”, Journal of Chemical, Biological and Physical Sciences (JCBPS), Vol. 3, No. 2. ISSN 2249-1929. 